University of Nebraska - Lincoln

DigitalCommons@University of Nebraska - Lincoln

Faculty Papers and Publications in Animal

Science

Animal Science Department

March 1969

\title{
Changes in Body Weight and Composition of Adult Nongravid Female Rats Deprived of Dietary Protein
}

\author{
W. G. Pond \\ Ithaca, New York \\ L. Dale Van Vleck \\ University of Nebraska-Lincoln, dvan-vleck1@unl.edu \\ E. F. Walker Jr. \\ Ithaca, New York \\ C. F. Eisenhard \\ Ithaca, New York \\ J. R. O'Connor \\ Ithaca, New York
}

Follow this and additional works at: https://digitalcommons.unl.edu/animalscifacpub

Part of the Animal Sciences Commons

Pond, W. G.; Van Vleck, L. Dale; Walker, E. F. Jr.; Eisenhard, C. F.; and O'Connor, J. R., "Changes in Body Weight and Composition of Adult Nongravid Female Rats Deprived of Dietary Protein" (1969). Faculty Papers and Publications in Animal Science. 175.

https://digitalcommons.unl.edu/animalscifacpub/175

This Article is brought to you for free and open access by the Animal Science Department at DigitalCommons@University of Nebraska - Lincoln. It has been accepted for inclusion in Faculty Papers and Publications in Animal Science by an authorized administrator of DigitalCommons@University of Nebraska - Lincoln. 
From The Journal of Nutrition Authors' Statement and Copyright Release Form (p. 3):

e. Authors may post a link on a personal website that directs readers to the article on The Journal of Nutrition website (www.jn.nutrition.org); full text of the final, published article can not be posted on personal or institutional websites or repositories that are accessible to the public.

\title{
Changes in Body Weight and Composition of Adult Nongravid Female Rats Deprived of Dietary Protein
}

\author{
W. G. Pond, L. D. Van Vleck, E. F. Walker, Jr., C. F. Eisenhard, and J. R. \\ O'Connor
}

Department of Animal Science

New York State College of Agriculture

Cornell University

Ithaca, New York

Seventy-six young adult nongravid female rats of the Carworth strain were used in two experiments to study the effect of dietary protein deprivation on body weight, feed consumption, body composition and serum protein concentration. Semipurified diets containing glucose, corn oil, vitamins and minerals with or without casein (protein-free $=\mathrm{PF}, 14 \%$ casein $=\mathrm{C}$ ) were fed ad libitum in both experiments to rats caged in individual wire-bottom cages. Feeding the PF diet for up to 26 days resulted in a continuous weight loss over the entire period. The average loss in body weight as a percentage of initial weight of PF rats in experiments 1 and 2 was 32.9 and 25.7, respectively. Weight loss during 9 days in rats fed the PF diet was restored within 8 days following transfer to the $C$ diet. Feed consumption was reduced only moderately by the PF diet, suggesting a large loss of ingested calories by excretion or metabolism to carbon dioxide and water. Body composition data supported this and indicated a greater relative loss of body energy than of body protein in PF rats. Blood serum protein concentration was reduced moderately $(P<0.05)$ in rats fed the PF diet. The absolute loss of serum protein may have been greater than suggested by the concentration if it is assumed that there was a reduction in blood volume associated with the observed weight loss. Blood serum protein concentration therefore does not appear to be as sensitive an index of protein nutrition in the adult as in the young animal. Final body energy, protein and water content were less in PF rats than in C rats in experiment 2 by an average of $176.5 \mathrm{kcal}(36 \%), 10.9 \mathrm{~g}(23 \%)$ and $41.7 \mathrm{~g}$ (28\%), respectively. Energy concentration (kilocalories per gram dry weight) was $11 \%$ greater in $C$ than in PF rats (5.8 versus $5.2 \mathrm{kcal} / \mathrm{g}$ ). These data indicate that the adult female nongravid rat can survive a loss of at least one-third of body energy and one-fourth of body protein induced by protein deprivation without developing severe hypoproteinemia, emaciation and edema.

Manuscript submitted July 17, 1968.

Published in Journal of Nutrition Vol. 97 No. 3 March 1969, pp. 343-347

Copyright (c) 1969 by American Society for Nutrition.

Online at: http://jn.nutrition.org/cgi/reprint/97/3/343 